\title{
Multilevel Analysis on the Contextual Effect of the Integrated Health Post Activity on Development of Children Under Five in Kubu Raya, West Kalimantan
}

\author{
Lolita'), Yulia Lanti Retno Dewi²), Bhisma Murti') \\ 1)Masters Program in Public Health, Universitas Sebelah Maret \\ 2)Department of Public Health, Faculty of Medicine, Universitas Sebelas Maret
}

\begin{abstract}
Background: It is estimated that 200 million children in developing countries do not develop optimally. Child development is a complex improvement in body structure and function that include gross and fine motoric, speech, language, socialization, and independence aspects of development. The success of children in achieving optimal development determines the future of a nation. The purpose of this study was to analyze the contextual effect of integrated health post (posyandu) in child development in Kubu Raya District, West Kalimantan.

Subjects and Method: This study was a cross sectional conducted at 25 integrated health post in Kubu Raya District, West Kalimantan, from November to December 2018. A sample 200 of children under five was selected by simple random sampling. The dependent variable was child development. The independent variables were maternal age at marriage, maternal education, parental income, parenting style, birth weight, birth length, child development monitoring, child development intervention, and integrated health post strata. Data collection was conducted using questionnaire and analyzed using multilevel logistic regression analysis in Stata 13.

Results: Child development disorder increased with early maternal age at marriage $(b=3.18 ; 95 \%$ $\mathrm{CI}=0.77$ to $5.59 ; \mathrm{p}=0.010)$, but decreased with high maternal education $(\mathrm{b}=-2.22 ; 95 \% \mathrm{CI}=-3.92$ to $-0.52 ; \mathrm{p}=0.010)$, high parental income $(\mathrm{b}=-4.01 ; 95 \% \mathrm{CI}=-6.55$ to $-1.47 ; \mathrm{p}=0.002)$, proper parenting style $(b=-2.89 ; 95 \% \mathrm{CI}=-5.18$ to $-0.60 ; \mathrm{p}=0.013)$, normal birth weight $(\mathrm{b}=-2.87 ; 95 \%$ $\mathrm{CI}=-4.80$ to $-0.95 ; \mathrm{p}=0.003)$, normal birth length $(\mathrm{b}=-3.13 ; 95 \% \mathrm{CI}=-5.63$ to $-0.63 ; \mathrm{p}=0.014)$, child development monitoring $(b=-2.9795 \% \mathrm{CI}=-5.58$ to $-0.36 ; \mathrm{p}=0.025)$, and child development intervention ( $\mathrm{b}=-3.53 ; 95 \% \mathrm{CI}=-6.19$ to $-0.87 ; \mathrm{p}=0.009)$. The integrated health post had $\mathrm{a}$ contextual effect on child development with ICC $=19.9 \%$.

Conclusions: Child development disorder increases with early maternal age at marriage, but decreased with high maternal education, high parental income, proper parenting style, normal birth weight, normal birth length, child development monitoring, and child development intervention. The integrated health post has a contextual effect on child development.
\end{abstract}

Keywords: child development, children under five, multilevel analysis

\section{Correspondence:}

Lolita. Public Health Masters Program, Universitas Sebelas Maret, Jl. Ir Sutami 36A, Surakarta, Central Java, Indonesia. Email : Patricialolita25@gmail.com Seluler: 082328463344

\section{BACKGROUND}

National Health Development is one of the government's efforts to improve the quality of life for the people of Indonesia. National Health Development will continue to be pursued by the government. Healthy human resources are a measure of the success of National Health Development. One of the indicators of quality human resources is the Human Development Index (Ministry of Health 2016). One of SDG's goals is to ensure that all human beings can fulfill their potential in dignity and equality (Richter, et al 2016). Optimal development of the nation's children influences progress 
in a nation in order to achieve optimal development must begin early.

Developmental aspects in toddlers include physical and motoric, cognitive, social-emotional and language development. An estimated 200 million children worldwide cannot fulfill optimal development potential because of poverty, poor health and an environment that is not supportive (Ford and Stein 2015).

\section{SUBJECTS AND METHOD \\ 1. Study Design}

The type of research used in this study is quantitative. The design of this study is an observational analytic study with a cross sectional approach. The study was conducted in 25 Posyandu in Kubu Raya District in November 2018 - December 2018.

\section{Population and Samples}

The source population in this study was toddlers aged 12-6o months in Kubu Raya District, West Kalimantan amounting to 200 research subjects. The sampling uses simple random sampling technique.

\section{Study Variables}

The dependent variable was child development. The independent variables were maternal age at marriage, education, income, parenting style, birth weight, length of birth, posyandu monitoring, posyandu intervention, and posyandu strata.

\section{Operational Definition of Variables}

Child development was defined as the achievement of gross motor, fine motor, speech/language, and social/ independence skills. Data collection was done using KPSP. The measurement scale used is in the form of continuous data with the results of measuring $\mathbf{1}=$ deviant development $(<7$ items); $\mathrm{o}=$ development accordingly $(\geq 7$ items).

The operational definition of the age of marriage for a mother is the age of the mother when she first married. Data collection was done using questionnaires. The scale used is categorical data with the results of measuring $1=$ early marriage ( $<20$ th); $\mathrm{O}=$ not married early ( $\geq 20$ years).

The operational definition of maternal education is the last formal education level that is taken based on the last diploma owned. Data collection was done using questionnaire. The measurement scale used is categorical data with the results of measuring $\mathrm{O}=$ low education (elementary and junior high school); $1=$ higher education (high school and college).

The operational definition of parental income is the average total income in the form of money obtained by the father and mother each month. Data collection was done using questionnaire sheets. The measurement scale used was in the form of continuous data with a measure of $\mathrm{O}=$ low ( $<$ minimum wage); $1=$ high $(\geq$ minimum wage).

Operational definition of child care is a system, method, or pattern applied by parents in caring for children under five related to developments that include patterns of nutrition, hygiene, and treatment. Data collection was done using questionnaire sheets. The measurement scale used was in the form of continuous data with measuring results $\mathrm{O}=$ inappropriate parenting $(<19.21)$; $1=$ proper parenting ( $\geq$ 19.21).

Definition of Operational Birth weight is the body weight of the research subject in grams measured within 24 hours after birth. The measuring instrument used is baby scales. Data collection was conducted using questionnaires and KIA books. The measurement scale used was categorical data with a measurement of $\mathrm{o}=$ Low Birth Weight ( $>2500$ grams); 1 = Normal Birth Weight ( $\geq 2500$ grams).

Birth length is the length of the infants birth body measured by health 
Journal of Maternal and Child Health, 2019, 4(4): 222-229

https://doi.org/10.26911/thejmch.2019.04.04.01

workers within 24 hours after birth and using an infantometer is measured in $\mathrm{cm}$. Data collection was done using questionnaire and KIA book. The measurement scale used is categorical data with a measurement of $\mathrm{o}=$ low birth length $(<48$ $\mathrm{cm}) ; 1=$ normal birth length $(\geq 48 \mathrm{~cm})$.

The definition of surgery for toddlers' development monitoring at the posyandu is the regularity of children's visits to the posyandu to participate in the posyandu activities for the past 6 months. Data collection was done using a questionnaire. The measurement scale used was in the form of continuous data with a measurement of $0=$ low ( $<4$ visits); $1=\operatorname{good}(\geq 4$ visits).

The operational definition of toddler development interventions at the posyandu is the activities of intervention, counseling, and referrals at the posyandu obtained by the research subject. Data collection was done using questionnaires. The measurement scale used was in the form of continous data with the results of measuring $\mathrm{o}=$ Not done (the mother has never received counseling, counseling, or referral regarding toddler development problems); 1 = Done (mothers have received counseling, counseling, or referrals regarding the development of toddlers).

The operational definition of posyandu strata is the level of development of posyandu based on the scope of activities, number of cadres, measurements and additional programs.

\section{Study Instruments}

Data on maternal marriage age, maternal education, parents' income, parenting, posyandu monitoring, posyandu intervention activities were obtained using questionnaire. Data on the development of toddlers were collected using KPSP and the posyandu strata based on the District Health Office report.

\section{Data Analysis}

Univariate analysis was conducted to see the frequency distribution and characteristics of the research subjects. Bivariate analysis was conducted to study the relationship between development of toddlers with independent variables with chi-square test, with a confidence level of CI of $95 \%$. Furthermore, multivariate analysis was performed using logistic regression using a multilevel approach.

\section{Research Ethics}

The study was carried out based on research ethics, namely inform consent, anonymity, confidentiality, and ethical ethical clearance. Ethical clearance in this study was obtained from Faculty of Medicine, Universitas Sebelas Maret, Surakarta, Central Java, Indonesia.

\section{RESULTS \\ 1. Sample Characteristics}

The results showed that most subjects were at 12 months 36 months of age at $57 \%$. The sex of the research subjects was $59.0 \%$ male and $49.5 \%$ female. Table 1 . Shows the characteristics of the research subject.

\begin{tabular}{lll}
\multicolumn{3}{l}{ Table 1. Sample Characteristics } \\
\hline Characteristics & n & \% \\
\hline Age & & \\
12-36months & 114 & 57 \\
37-6omonths & 86 & 43 \\
Gender & & \\
Male & 119 & 59.0 \\
Female & 81 & 49.5 \\
\hline
\end{tabular}

\section{UnivariateAnalysis}

Table 2 shows that 60 premature married mothers (30\%), those who did not marry early are 140 subjects (70\%). Mothers with low education were 53 subjects (26.5\%), and mothers with high education were 147 subjects (73.5). Low incomeparentsconsist of 50 subjects (25\%) and high parents' income consist of 150 subjects (75\%). Proper parenting consists of 139 subjects 
(69.5\%) and inappropriate parenting consists of 61 subjects (30.5\%). Low birth weight is 64 subjects (32\%), normal birth weight is 136 subjects (69.5\%). Short-born body length consist of 48 subjects (24\%), normal birth length consist of 152 subjects (76\%). Monitoring of the posyandu was 62 subjects (31\%). The posyandu intervention was not carried out by 62 subjects (31\%) and did by 138 subjects (69\%).

Table 2.The Results of UnivariateAnalysis

\begin{tabular}{lcc}
\hline \multicolumn{1}{c}{ Variable } & Frequency & \% \\
\hline Maternal age when married & 60 & 30.0 \\
Early & 140 & 70.0 \\
Not early & & 26.5 \\
Education & 53 & 73.5 \\
Low & 147 & 25.0 \\
High & & 75.0 \\
Family Income & 50 & \\
Low & 150 & 30.5 \\
High & & 69.5 \\
Parenting Style & 61 & 32.0 \\
Appropriate & 139 & 68.0 \\
Inappropriate & & \\
Birth Weight & 64 & 24.0 \\
LBW & 136 & 76.0 \\
Normal birth weight & & \\
Birth length & 48 & 31.0 \\
Normal & 152 & 69.0 \\
Posyandu Monitoring & & \\
Poor & 62 & 31.0 \\
Good & 138 & 69.0 \\
Posyandu Intervention & & \\
No & 138 & \\
\hline
\end{tabular}

Table 3. Multivariate Analysis

\begin{tabular}{|c|c|c|c|c|}
\hline \multirow{2}{*}{ Child Development } & \multirow{2}{*}{ b } & \multicolumn{2}{|c|}{ CI 95\% } & \multirow[b]{2}{*}{$\mathbf{p}$} \\
\hline & & Lower Limit & Upper Limit & \\
\hline \multicolumn{5}{|l|}{ Fixed Effect } \\
\hline Maternal Age of Marriage & 3.28 & 0.77 & 5.59 & 0.010 \\
\hline Maternal Education & -2.22 & -3.92 & -0.52 & 0.010 \\
\hline Parental Income & -1.29 & -6.55 & -1.47 & 0.002 \\
\hline Parenting & -2.89 & -5.18 & -0.60 & 0.013 \\
\hline Birth Weight & -2.87 & -4.80 & -0.95 & 0.003 \\
\hline Birth Length & 3.13 & -5.63 & -0.63 & 0.014 \\
\hline Health Center Monitoring & -2.97 & 0.02 & 5.58 & -0.36 \\
\hline Health Center Intervention & -3.53 & 0.009 & 6.19 & -0.87 \\
\hline \multicolumn{5}{|l|}{ Random Effect } \\
\hline \multicolumn{5}{|l|}{ Health Center } \\
\hline Var (constants) & 0.81 & 4.36 & 19.08 & \\
\hline $\mathrm{N}$ observation $=200$ & & & & \\
\hline N Group = 25 & & & & \\
\hline $\mathrm{N}$ Average $=8$ & & & & \\
\hline Log likelihood = - 33.77 & & & & \\
\hline $\mathrm{ICC}=19.90 \%$ & & & & \\
\hline
\end{tabular}


Journal of Maternal and Child Health, 2019, 4(4): 222-229

https://doi.org/10.26911/thejmch.2019.04.04.01

\section{Multilevel Analysis}

Multivariate analysis used a multilevel logistic regression method and was analyzed by using STATA13. Multivariate analysis explained the effect of more than one independent variable on 1 dependent variable. Table 3 showed that there was a significant effect of maternal age in marriage, maternal education, parent's income, parenting, birth weight, birth length, health center monitoring, and health center intervention. Developmental deviations. Early age of marriage $(b=3.18 ; 95 \% \mathrm{CI}=$ 0.77 up to $5.59 ; \mathrm{p}=0.10$ ), increase developmental disorders in toddlers. High maternal education $(b=-2.22 ; 95 \% \mathrm{CI}=-3.92$ up to $-0.52 ; \mathrm{p}=0.10)$, high income $(\mathrm{b}=-4.01$; $95 \% \mathrm{CI}=-6.55$ to $-1.47 ; \mathrm{p}=0,002)$, good parenting $(\mathrm{b}=-2.89 ; 95 \% \mathrm{CI}=-5.18$ up to $0.60 ; \mathrm{p}=0.13)$, normal birth weight $(\mathrm{b}=$ $2.87 ; 95 \% \mathrm{CI}=-4.80$ to $-0.95 ; \mathrm{p}=0.003)$, normal birth length $(b=-3.13 ; 95 \% \mathrm{CI}=-$ 5.63 to $-0.63 ; \mathrm{p}=0.014)$, good health center monitoring $(\mathrm{b}=-2.9795 \% \mathrm{CI}=-5.58$ to $0.36 ; \mathrm{p}=0.025$ ), good health center intervension $(b=-3.53 ; 95 \% C I=-6.19$ to -0.87 ; $\mathrm{p}=0.009$ ) can decrease the incidence of developmental disorders in toddlers.

Community health center had contextual effect on child development 19.90\%.

\section{DISCUSSIONS}

\section{The effect of maternal age in marriage on child development}

In this study, there was a significant relationship between the age of mother in marriage and the development of toddlers. In 2012, in Indonesia, the number of married women aged 10-14 years old was 4.2\%, while married women aged 15-19 years old were $41.8 \%$ (BKKBN, 2013). A study conducted by UNICEF (United Nations International Emergency Fundation) in 2011 stated that children in Indonesia experienced emotional symp- toms, behavioral problems, hyperactivity, and problems related to peers by $21.2 \%$ were children of early marriage.

This was in line with a study done by Efevbera et al (2017) which stated that toddlers born to women under the age of 18 years old have a significant opportunity to be on a deviant development path, the four domains of the development of toddlers have the potential to be hampered compared to mothers who get married at a more mature age.

\section{The effect of maternal education on child development}

Maternal education played a very important role in children's development. The results of this study indicated that there was a significant relationship between maternal education and development of toddlers. The higher the maternal education, the lower the developmental deviation of children by -2.22 statistically.

This was in line with a study by Ye et al, in 2018 which stated that $40.3 \%$ of mothers who have low or moderate level of education have children with aberrant development of the gross motor and fine motor domains, this was related to the mother's IQ. Mothers with low or middle education tend to have lower IQ than mothers with higher level of education.

\section{The effect of family income on child development}

The results of this study indicated that there was a significant influence of parents' income and the development of toddlers. High parents' income can reduce the possibility of deviant development in toddlers. This research was in line with the results of study conducted by Zachrisson and Dearing in 2015. Zachrisson and Dearing stated that parents' income can influence the development of children, especially toddlers (2-5 years old). 
Developmental deviations almost occurred in every development domain.

\section{The effect of parenting on child development}

The results of this study indicated that there was a significant effect of parenting and the development of toddlers. Good parenting can reduce the possibility of irregularities in child development. This result was in line with Escamilla and Moran (2016) which stated that although nutritional interventions were very important for children's development, nutrition was not enough to support children's development. There were external factors that must be considered including early parenting style and stimulation. Responsive parenting included responsive feeding and hygine practice also influenced the development of children to reach the development potential of toddlers.

\section{The effect of birth weight on child development}

The results of this study indicated that there was an effect of birth weight and the development of toddlers. Normal birth weight can reduce the developmental deviation in toddlers. Stolt (2014) in his study stated that toddlers who were born with low birth weight have weaker language skills in the second year than children who were born with normal birth weight.

This result was in line with the study by Ribeiro in 2017, which stated thatbabies born with low birth weight can experience developmental delays and differ from babies who were born with normal birth weight. Research conducted by Datar and Jacknowitz in 2009 also showed that there was an effect between low birth weight and the development of toddlers, the lower the birth weight, the greater the influence to experience developmental deviations.

\section{The effect of birth length on child development}

The results of this study indicated that there was a significant effect of birth length and the development of toddlers. Normal birth length can reduce the incidence of developmental deviations in toddlers. The results of this study were in line with the research conducted by Lee in 2017 which stated that there was an effect of anthropometric calculations at birth on motor neuron development at the beginning of birth, at the age of below 5 years old, this could affect motor, cognitive and language development.

\section{The effect of health center moni- toring on child development}

In this study, there was a statistically significant value on the effect of monitoring in health center on the development of toddlers, good monitoring at health center can reduce the deviations in toddlers' development. Health center was the first place for children to monitor their nutritional status. If the health center was underutilized by parents, then the developmental status of children cannot be monitored regularly and this resulted in the slow handling of developmental deviations that occur(Khalifatunisak, 2018)

\section{The effect of health center inter- vension on child development}

The results of this study indicated that there was a significant effect of intervension in health center and the development of toddlers. The existence of health center was very necessary in bringing promotive and preventive efforts to the community closer, especially related to efforts to improve public health status which included the development of toddlers, as well as maternal and child health efforts (Ministry of Health of the Republic of Indonesia 2011). Counseling and referrals to the develop- 
Journal of Maternal and Child Health, 2019, 4(4): 222-229

https://doi.org/10.26911/thejmch.2019.04.04.01

ment of toddlers were some of the coverage of health center activities.

\section{The effect of health center strata on child development}

The results of this study indicated that there was a significant effect of health center strata/level and the development of toddlers. Health Center was one form of Community-Based Health Effort that was managed and organized from, by, for and with the community (Ministry of Health, 2011). One of the goals of health center was to maintain and improve infant health, toddlers got basic health services such as immunization, nutrition and prevention of diseases which conducted once a month in a place that has been agreed upon and affordable by the community so that maximum service can be given. One of the services for toddlers was screening for developmental deviations in children (Ministry of Health,2011).

Based on the results of the research, it can be concluded that there was a statistically significant effect of maternal age in marriage, maternal education, parental income, parenting, birth weight, birth length, health center monitoring, and health center intervention on the development of toddlers. Variations at the health center level showed a contextual effect on the development of toddlers.

\section{REFERENCES}

Badan Pusat Statistik (BPS). 2012. Survei Demografi dan Kesehatan Indonesia (SDKI) 2012. Jakarta.

Badan Pusat Statistik (BPS), UNICEF 2016. Analisis Data Perkawinan Usia Anak di Indonesia. Jakarta : Badan Pusat Statistik

Datar, A. Jacknowitz, A. 2009. Birth weight effects on children's mental, motor, and physical development: Evidence from Twins Data. Matern Child
Health J. 13:780-794. Doi: 10.1007/s10995-009-0461-6

Efevbera, Y,. et al. 2017. Girl child marriage as a risk factor for early childhood development and stunting. Social Science and Medicine Journal. DOI: 10.1016/j.socscimed.2017.05.027

Escamilla, P R., Moran, V. H. 2016. The role of nutrition in integrated early child development in the 21st century: contribution from theMaternal and Child Nutritionjournal. Maternal \& Child Nutrition, 13(1), e12387. doi:10.1111/mcn.12387

Ford, N D., Stein, A D. 2015. Risk factors affecting child cognitive development: a summary of nutrition, environment, and maternal-child interaction indicators for sub-Saharan Africa. Journal of Developmental Origins of Health and Disease (2016), 7(2), 197217. doi:10.1017/S2040174415001427

Kemenkes RI. 2016. Pedoman Umum Program Indonesia Sehat denga Pendekatan Keluarga. Jakarta

Kemenkes RI. 2016. Pedoman Pelaksanaan Stimulasi, Deteksi dini dan Intervensi Dini Tumbuh Kembang Anak. Jakarta Kemenkes RI. 2011. Pedoman Umum Pengelolaan Posyandu. Jakarta : Kementerian Kesehatan RI. 2011 ISBN 978602-9364-87-

Kemenkes RI. 2011. Riset Hasil Kesehatan Daerah. Direktorat Jendral Kesehatan Ibu dan Anak. Jakarta

Khalifatunisak, A., Salimo, H., Dewi, Y L R. Multilevel Analysis on the Determinants of Overweight among Children Under Five in Kediri, East Java. eISSN: 2549-0257. Journal of Maternal and Child Health (2018), 3(4): 261-268 https://doi.org/10.26911/thejmch.2018.03.04.03 262

Maggi, S., Irwin Lori J, Siddiqi A, Hertzman C. 2010. The social determinants 
of early child development: An overview. Jurnal of Pediatric and Child Health. doi:10.1111/j.1440-1754.2010.01817.x

Murti B. 2018. Prinsip dan Metode Riset Epidemiologi Edisi keempat. Surakarta: Program Studi Ilmu Kesehatan Masyarakat, Program Pascasarjana, Universitas Sebelas Maret.

Ribeiro, CC. Regina, MOP. et al. 2017. Development skills of children born premature with low and very low birth weight. DOI: 10.1590/2317-1782/20162016058

Richter, L M, Lombardi J, et al. 2016. Investing in the foundation of sustainable development: pathways to scale up for early childhood development. doi: 10.1016/So140-6736(16): 31698-1

Stolt, S. Korja, R. et al 2014. Early relations between language development and the quality of mother child interaction in very low birth weight children. Early Human DevelopmentVolume 90, Issue 5, May 2014, Pages 219225https://doi.org/10.1016/j.earlhum dev.2014.02.007

Ye A, Yan S, Huang K, et al. 2018. Maternal intelligence quotient and motor development in early childhood: The mediating role of mother's education. doi:10.1111/jpc.14123

Zachrisson, HD, Dearing. E 2015. Family Income Dynamics, Early Childhood Education and Care, and Early Child Behavior Problems in Norway. doi: 10.1111/cdev.12306

Lee, J J. ,Kapur K., Rodrigues, E G., et al. 2017. Anthropometric measures at birth and early childhood are associated with neurodevelopmental outcomes among Bangladeshi children aged 2-3years. Science of the Total Environment. Elsevier. doi.org/10.1016/j.scitotenv.2017.06.168 